\title{
Liquid biopsy in gastrointestinal stromal tumors: a novel approach
}

\author{
Margherita Nannini ${ }^{1}$, Annalisa Astolfi ${ }^{2}$, Milena Urbini ${ }^{2}$, Guido Biasco ${ }^{1,2}$ and Maria A Pantaleo ${ }^{1,{ }^{*}}$
}

\begin{abstract}
The role of molecular analysis in the management of gastrointestinal stromal tumors (GIST) remains indisputable. To date, tumor tissue extracted from specimens obtained by surgical or biopsy procedures has been the only source of the tumor DNA required for the molecular and genomic assessment of cancer. However, tumor tissue sampling has several clinical limitations: for example, the invasiveness of these procedures precludes repeated sampling. Thus, it is possible to obtain only a static molecular picture of the disease, a picture that lacks the inter- and intra-metastatic molecular heterogeneity that characterizes most GIST. In contrast, circulating tumor DNA obtained from a patient's bloodstream, known as liquid biopsy, can theoretically overcome the limitations of tissue biopsies and provide the same molecular and genomic information. GIST are recognized as a paradigm of molecular biology among solid tumors. Although few but promising data on liquid biopsy in GIST have been accumulated to date, these tumors may provide the optimal field for application of this challenging approach.
\end{abstract}

Keywords: Gastrointestinal stromal tumor, Mutational analysis, KIT, Platelet-derived growth factor receptor alpha, Circulating tumor DNA, Liquid biopsy

\section{Introduction}

The role of molecular analysis in the management of gastrointestinal stromal tumors (GIST) remains unexplored [1,2]. Knowledge of mutational status provides clinicians with a mandatory guide to therapeutic decision making concerning GIST patients with advanced disease [3-5]. Mutational analysis has also been advocated in the adjuvant setting [6-8]: a recent trial on the relationship between tumor genotype and benefits of adjuvant imatinib reported that GIST with a KIT exon 11-deletion respond positively to treatment, with a significantly longer recurrence-free survival compared with placebo. However, this benefit was not observed for GIST KIT exon 11 point mutations and insertions, or KIT exon 9 or KIT/plateletderived growth factor receptor alpha (PDGFRA) wild type (WT) [2].

To date, tumor tissue extracted from specimens obtained by surgical or biopsy procedures has been the only source of the tumor DNA required for the molecular and genomic assessment of cancer. However, such tumor tissue

\footnotetext{
*Correspondence: maria.pantaleo@unibo.it

'Department of Specialized, Experimental and Diagnostic Medicine, Sant'Orsola-Malpighi Hospital, University of Bologna, Bologna 40138, Italy ${ }^{2 " G i o r g i o ~ P r o d i " ~ C a n c e r ~ R e s e a r c h ~ C e n t e r, ~ U n i v e r s i t y ~ o f ~ B o l o g n a, ~ B o l o g n a ~}$ 40138, Italy
}

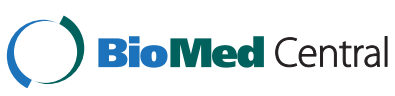

(c) 2014 Nannini et al.; licensee BioMed Central Ltd. This is an Open Access article distributed under the terms of the Creative Commons Attribution License (http://creativecommons.org/licenses/by/4.0), which permits unrestricted use, distribution, and reproduction in any medium, provided the original work is properly credited. The Creative Commons Public Domain Dedication waiver (http://creativecommons.org/publicdomain/zero/1.0/) applies to the data made available in this article unless otherwise stated. sampling has several clinical limitations: because it is obtained by invasive procedures that can have complications, it cannot be repeated frequently. In the absence of serial samples for analysis, only a static molecular picture of the disease, a picture that lacks the inter- and intrametastatic molecular heterogeneity characteristic of most GISTs, is available [9,10]. Moreover, tumor tissue in formalin-fixed paraffin-embedded blocks is not optimal for wide genome analysis, which requires high-throughput technologies for which fresh DNA is more suitable.

In the scenario under review here, circulating tumor DNA (ctDNA) obtained from a patient's bloodstream, known as liquid biopsy, can theoretically overcome all the limitations of tissue biopsies and provide the same molecular and genomic information [11]. Because blood sampling is minimally invasive, it can be performed at any time during the course of the disease, allowing dynamic assessment of molecular changes in tumors over time. Moreover, it can provide the fresh tumor DNA needed for whole genome and exome analyses.

ctDNA investigations in cancer patients are increasingly being performed, supporting the different potential applications of this approach. Preliminary studies in patients with melanoma, ovarian, breast, prostate, and colon cancers have 
shown that the amount of ctDNA correlates with the tumor burden, suggesting a potential role for ctDNA as a surrogate marker of tumor response to treatment [12-16]. Additionally, detection of ctDNA after radical surgery or curative therapies indicates the presence of minimal residual disease and may thus identify patients who will experience tumor recurrence [12]. Other studies have shown that serial analysis of ctDNA during treatment can provide a dynamic picture of molecular disease changes, suggesting that this noninvasive approach could also be used to monitor the development of secondary resistance and identify heterogeneous subclonal populations of tumor cells developing during the course of treatment [17]. Such a monitoring application should be extremely useful during treatment of cancer with tyrosine-kinase inhibitors (TKIs). Finally, different strategies for detecting novel chromosomal alterations in plasma, such as rearrangements and amplification or epigenetic changes, have recently been developed, suggesting that ctDNA could also be used for detecting new tumorderived variants for genotyping purposes [18-20].

\section{Review}

Because the application of liquid biopsy in GIST has only been reported in the last year, few but promising data are now available $[21,22]$. The feasibility of liquid biopsy and its application in GISTs was reported for the first time at the 2013 ASCO Annual Meeting [21,22]. Using both Sanger sequencing on tumor tissue and Beads Emulsion Amplification Magnetics technology on plasma, Demetri et al. have analyzed the kinase genotypes in a subgroup of GIST patients in a phase III GRID trial [21]. They found $84 \%$ concordance between plasma and tissue for detection of primary KIT mutations. Additionally, they more easily detected secondary mutations in plasma (47\%) than in tissue $(12 \%)$. In contrast, the assay was less sensitive for the detection of primary KIT exon 11 mutations in plasma DNA (12\% vs $43 \%)$, this apparent discrepancy being partly attributable to the study design, which was specifically targeted to secondary mutations, but mostly to the extensive heterogeneity of primary KIT exon 11 mutations that hampers the development of specific assays for each possible mutation carried by the tumor. These findings highlight a possible limitation of liquid biopsy that is shared by all other technologies specifically designed to identify KIT/PDGFRA mutations in GIST management; namely, the wide variability of tyrosine kinase mutations. Thus, less targeted approaches may be better able to provide a complete sequence of the hotspot exons such as CAPPSeq or TAm-Seq. However, even in this scenario the very large insertions and deletions barely detected by massively parallel sequencing would constitute a drawback $[23,24]$. Maier et al. retrospectively used 25 different allele-specific L-polymerase chain reaction assays covering KIT and PDGFRA mutations to examine 291 plasma samples from
38 GIST patients and correlated the detection of mutated ctDNA with disease status (active disease vs complete response [CR]) [22]. Interestingly, they found that, in the clinical setting, more patients with active disease, defined as patients having at least one lesion progressing or responding to treatment, had positive results than did CR patients without evidence of residual disease after surgery. They also examined whether the amount of ctDNA correlated with tumor radiological response and reported repeated positive test results and increasing mutant ctDNA in patients with disease progression, negative to positive conversions in patients with relapse, and positive to negative conversions in patients responding to TKIs. Taken together, these findings indicate that mutant ctDNA can be detected and quantified in the plasma of GIST patients and, notably, that the amount of mutant ctDNA correlates with tumor response, suggesting that this approach is feasible and can be used as a surrogate biomarker for predicting both tumor response and relapse in GIST patients.

Although very few data have been accumulated to date, liquid biopsy seems to be a promising tool in GIST management, offering a wide spectrum of clinical applications. The well-known kinase genotype and its relationship with tumor response to TKIs has made GIST a paradigm of molecular biology among solid tumors and provides a strong rationale for applying liquid biopsy in this disease. In particular, the possibility of taking serial blood samples to assess real-time molecular modifications during the course of treatment may identify the development of heterogeneous resistant clones, thereby optimizing the timing of changes in therapeutic strategy. However, because the therapeutic armamentarium available for advanced GIST is limited, this noninvasive approach should not be applied only to anticipate changes in treatment, but also to guide clinicians in re-challenging with drugs according to a rotation strategy.

In addition to offering a dynamic picture of molecular changes during the course of a disease that could serve as early biomarkers of tumor response to TKIs, other intriguing applications of liquid biopsy in GIST management are possible. First, it could be used to assess minimal residual disease after radical resection of a primary tumor, thus accurately identifying patients at high risk of recurrence for whom adjuvant treatment is indicated. Plainly, the main limitation of this application is the ability of the methods used to detect very small amounts of ctDNA; more sensitive assays should be developed for this purpose. Moreover, in the light of the extreme biological heterogeneity of GIST, especially those without the known KIT/PDGFRA or BRAF/RAS/NF1 or SDH mutations (termed WT GIST), liquid biopsy may be the best tool for obtaining a wide molecular picture of GIST by using whole genome analyses with high-throughput technologies, such as next-generation sequencing approaches. 
ctDNA could be used as a source for identifying novel chromosomal adaptations such as rearrangements and translocations, thus overcoming the limitations of creating fresh tissue banks. This would facilitate a more detailed molecular classification of this disease and shed light on new diagnostic and prognostic biomarkers and eventually new potential targets, thereby extending the therapeutic armamentarium for a subset of GIST. Finally, liquid biopsy could also be used to select patients for clinical trials according to their molecular profile, rather than relying solely on the standard clinical and pathological features adopted to date.

\section{Conclusions}

Liquid biopsy is emerging as one of the most challenging and promising tools in oncology. Because GIST are recognized as the paradigm of molecular biology in solid tumors, these tumors represent an optimal field in which to use this approach.

\section{Abbreviations}

PDGFRA: Platelet-derived growth factor receptor alpha; GIST: Gastrointestinal stromal tumor; ctDNA: Circulating tumor DNA; WT: Wild type; TKI: Tyrosinekinase inhibitor.

\section{Competing interests}

No authors have any non-financial competing interests to disclose.

\section{Authors' contributions}

All authors have participated in drafting, reading, and approving the final manuscript.

Received: 14 May 2014 Accepted: 7 July 2014

Published: 14 August 2014

\section{References}

1. ESMO/European Sarcoma Network Working Group: Gastrointestinal stromal tumors: ESMO Clinical Practice Guidelines for diagnosis, treatment and follow-up. Ann Oncol 2012, 23(Suppl 7):vii49-5.

2. Corless CL, Ballman KV, Antonescu CR, Kolesnikova V, Maki RG, Pisters PW, Blackstein ME, Blanke CD, Demetri GD, Heinrich MC, von Mehren M, Patel S, McCarter MD, Owzar K, DeMatteo RP: Pathologic and molecular features correlate with long-term outcome after Adjuvant Therapy of resected primary GI stromal tumor: The ACOSOG Z9001 trial. J Clin Oncol 2014, 32:1563-1570.

3. Heinrich MC, Corless CL, Demetri GD, Blanke CD, von Mehren M, Joensuu $H$, McGreevey LS, Chen CJ, Van den Abbeele AD, Druker BJ, Kiese B, Eisenberg B, Roberts PJ, Singer S, Fletcher CD, Silberman S, Dimitrijevic S, Fletcher JA: Kinase mutations and imatinib response in patients with metastatic gastrointestinal stromal tumor. J Clin Oncol 2003, 21:4342-4349.

4. Debiec-Rychter M, Dumez H, Judson I, Wasag B, Verweij J, Brown M, Dimitrijevic S, Sciot R, Stul M, Vranck H, Scurr M, Hagemeijer A, van Glabbeke M, van Oosterom AT, EORTC Soft Tissue and Bone Sarcoma Group: Use of c-KIT/PDGFRA mutational analysis to predict the clinical response to imatinib in patients with advanced gastrointestinal stromal tumours entered on phase I and II studies of the EORTC Soft Tissue and Bone Sarcoma Group. Eur J Cancer 2004, 40:689-695.

5. Debiec-Rychter $M$, Sciot $R$, Le Cesne A, Schlemmer $M$, Hohenberger $P$, van Oosterom AT, Blay JY, Leyvraz S, Stul M, Casali PG, Zalcberg J, Verweij J, Van Glabbeke M, Hagemeijer A, Judson I, EORTC Soft Tissue and Bone Sarcoma Group; Italian Sarcoma Group; Australasian Gastrolntestinal Trials Group: KIT mutations and dose selection for imatinib in patients with advanced gastrointestinal stromal tumours. Eur J Cancer 2006, 42:1093-1103.
6. Gronchi A: Risk stratification models and mutational analysis: Keys to optimising adjuvant therapy in patients with gastrointestinal stromal tumour. Eur J Cancer 2013, 49:884-892.

7. Sendur MA, Ozdemir NY, Akıncı MB, Uncu D, Zengin N, Aksoy S: Is exon mutation analysis needed for adjuvant treatment of gastrointestinal stromal tumor? World J Gastroenterol 2013, 19:144-146.

8. Nannini M, Pantaleo MA, Biasco G: Role of molecular analysis in the adjuvant treatment of gastrointestinal stromal tumours: it is time to define it. World J Gastroenterol 2013, 19:2583-2586.

9. Liegl B, Kepten I, Le C, Zhu M, Demetri GD, Heinrich MC, Fletcher CD, Corless CL, Fletcher JA: Heterogeneity of kinase inhibitor resistance mechanisms in GIST. J Pathol 2008, 216:64-74.

10. Desai J, Shankar S, Heinrich MC, Fletcher JA, Fletcher CD, Manola J, Morgan JA, Corless CL, George S, Tuncali K, Silverman SG, Van den Abbeele AD, van Sonnenberg E, Demetri GD: Clonal evolution of resistance to imatinib in patients with metastatic gastrointestinal stromal tumors. Clin Cancer Res 2007, 13:5398-5405.

11. Diaz LA Jr, Bardelli A: Liquid biopsies: genotyping circulating tumor DNA. J Clin Oncol 2014, 32:579-586.

12. Diehl F, Schmidt K, Choti MA, Romans K, Goodman S, Li M, Thornton K, Agrawal N, Sokoll L, Szabo SA, Kinzler KW, Vogelstein B, Diaz LA Jr: Circulating mutant DNA to assess tumor dynamics. Nat Med 2008, 14:985-990.

13. Shinozaki M, O'Day SJ, Kitago M, Amersi F, Kuo C, Kim J, Wang HJ, Hoon DS: Utility of circulating B-RAF DNA mutation in serum for monitoring melanoma patients receiving biochemotherapy. Clin Cancer Res 2007, 13:2068-2074

14. Dawson SJ, Tsui DW, Murtaza M, Biggs H, Rueda OM, Chin SF, Dunning MJ, Gale D, Forshew T, Mahler-Araujo B, Rajan S, Humphray S, Becq J, Halsall D, Wallis M, Bentley D, Caldas C, Rosenfeld N: Analysis of circulating tumor DNA to monitor metastatic breast cancer. N Engl J Med 2013, 368:1199-1209.

15. No JH, Kim K, Park KH, Kim YB: Cell-free DNA level as a prognostic biomarker for epithelial ovarian cancer. Anticancer Res 2012, 32:3467-3471.

16. Schwarzenbach $\mathrm{H}$, Alix-Panabières $C$, Müller I, Letang N, Vendrell JP, Rebillard X, Pantel K: Cell-free tumor DNA in blood plasma as a marker for circulating tumor cells in prostate cancer. Clin Cancer Res 2009, 15:1032-1038.

17. Murtaza M, Dawson SJ, Tsui DW, Gale D, Forshew T, Piskorz AM, JimenezLinan M, Bentley D, Hadfield J, May AP, Caldas C, Brenton JD, Rosenfeld N: Non-invasive analysis of acquired resistance to cancer therapy by sequencing of plasma DNA. Nature 2013, 497:108-112.

18. Leary RJ, Sausen M, Kinde I, Papadopoulos N, Carpten JD, Craig D, O'Shaughnessy J, Kinzler KW, Parmigiani G, Vogelstein B, Diaz LA Jr, Velculescu VE: Detection of chromosomal alterations in the circulation of cancer patients with whole-genome sequencing. Sci Trans/ Med 2012, 4:162ra154.

19. McBride DJ, Orpana AK, Sotiriou C, Joensuu H, Stephens PJ, Mudie LJ, Hämäläinen E, Stebbings LA, Andersson LC, Flanagan AM, Durbecq V, Ignatiadis M, Kallioniemi O, Heckman CA, Alitalo K, Edgren H, Futreal PA, Stratton MR, Campbell PJ: Use of cancer-specific genomic rearrangements to quantify disease burden in plasma from patients with solid tumors. Gene Chromosome Cancer 2010, 49:1062-1069.

20. Chan KC, Jiang P, Zheng YW, Liao GJ, Sun H, Wong J, Siu SS, Chan WC, Chan SL, Chan AT, Lai PB, Chiu RW, Lo YM: Cancer genome scanning in plasma: Detection of tumor-associated copy number aberrations, single-nucleotide variants, and tumoral heterogeneity by massively parallel sequencing. Clin Chem 2013, 59:211-224.

21. Demetri GD, Jeffers $M$, Reichardt $P$, Kang $Y-K$, Blay J-Y, Rutkowski $P$, Gelderblom $H$, Hohenberger P, Leahy Gordon M, von Mehren M, Joensuu H, Badalamenti G, Blackstein ME, Le Cesne A, Maki RG SP, Xu J-M, Nishida T, Kuss I, Casali PG: Mutational analysis of plasma DNA from patients (pts) in the phase III GRID study of regorafenib (REG) versus placebo (PL) in tyrosine kinase inhibitor (TKI)-refractory GIST: Correlating genotype with clinical outcomes. J Clin Oncol 2013, 31:10503.

22. Maier J, Lange T, Kerle I, Specht K, Bruegel M, Wickenhauser C, Jost $P$, Niederwieser D, Peschel C, Duyster J, von Bubnoff N: Detection of mutant free circulating tumor DNA in the plasma of patients with gastrointestinal stromal tumor harboring activating mutations of CKIT or PDGFRA. Clin Cancer Res 2013, 19:4854-4867.

23. Newman AM, Bratman SV, To J, Wynne JF, Eclov NC, Modlin LA, Liu CL, Neal JW, Wakelee HA, Merritt RE, Shrager JB, Loo BW Jr, Alizadeh AA, Diehn M: An 
ultrasensitive method for quantitating circulating tumor DNA with broad patient coverage. Nat Med 2014, 20:548-554.

24. Forshew T, Murtaza M, Parkinson C, Gale D, Tsui DW, Kaper F, Dawson SJ, Piskorz AM, Jimenez-Linan M, Bentley D, Hadfield J, May AP, Caldas C, Brenton JD, Rosenfeld N: Noninvasive identification and monitoring of cancer mutations by targeted deep sequencing of plasma DNA. Sci Transl Med 2012, 4:136ra68.

doi:10.1186/1479-5876-12-210

Cite this article as: Nannini et al:: Liquid biopsy in gastrointestinal stromal tumors: a novel approach. Journal of Translational Medicine 2014 12:210.

\section{Submit your next manuscript to BioMed Central and take full advantage of:}

- Convenient online submission

- Thorough peer review

- No space constraints or color figure charges

- Immediate publication on acceptance

- Inclusion in PubMed, CAS, Scopus and Google Scholar

- Research which is freely available for redistribution 